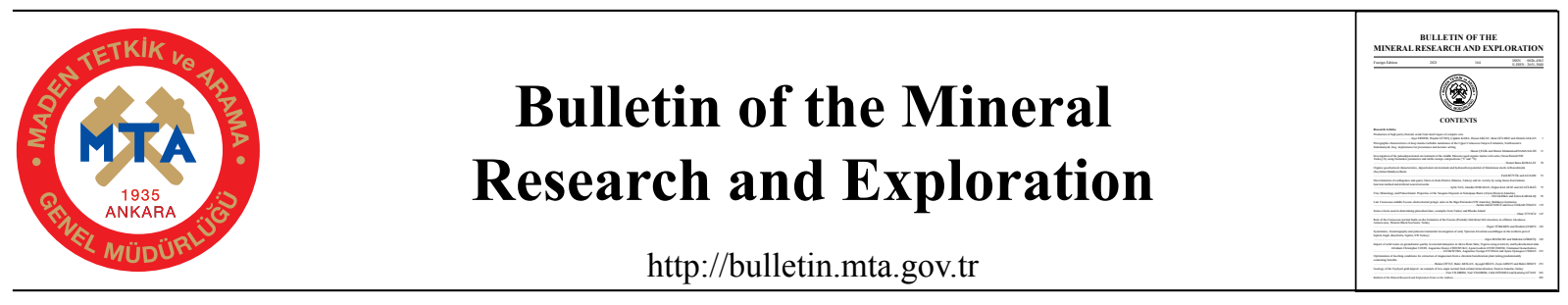

\title{
Optimization of leaching conditions for extraction of magnesium from a chromite beneficiation plant tailing predominantly containing lizardite
}

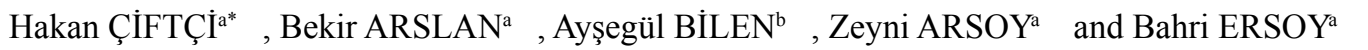

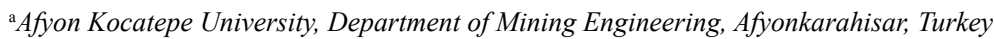 \\ ${ }^{\mathrm{b}}$ Ylldiz Technical University, Department of Metallurgy and Material Engineering, Ístanbul, Turkey
}

Research Article

Keywords:

Leaching, Lizardite, Magnesium, Amorphous silicate, Chromite plant tailing.

Received Date: 09.04.2020 Accepted Date: 17.11 .2020

\begin{abstract}
In this study, leaching experiments were performed for extraction of magnesium from a chromite beneficiation plant tailing predominantly containing lizardite. The X-ray fluorescence (XRF) and $\mathrm{X}$-ray diffraction (XRD) analyzes showed that the tailing sample contains $39.3 \mathrm{wt} . \% \mathrm{MgO}$ and consist of predominantly lizardite mineral. Hydrochloric acid $(\mathrm{HCl})$ and sulphuric acid $\left(\mathrm{H}_{2} \mathrm{SO}_{4}\right)$ were used as acids separately in leaching experiments. Acid concentration, leaching temperature, leaching time, and solid ratio were investigated as leaching parameters and optimized. Maximum magnesium extraction yield was determined to be nearly $98 \%$ for both acids under optimum leaching parameters which leaching temperature was $85^{\circ} \mathrm{C}$, solid ratio was $20 \mathrm{wt} . \%$, leaching time was 120 minutes, and acid concentrations were $6 \mathrm{M}$ for $\mathrm{HCl}$ and $4 \mathrm{M}_{\text {for }} \mathrm{H}_{2} \mathrm{SO}_{4}$. In addition, it was determined that the leaching residue as a solid state was mainly composed of amorphous silicate according to the XRD analysis. Dissolution rate data were explained using Jander equation. Mg dissolution process found to be diffusion controlled.
\end{abstract}

\section{Introduction}

Serpentine minerals, phyllosilicates with a nominal composition of $\mathrm{Mg}_{3} \mathrm{Si}_{2} \mathrm{O}_{5}(\mathrm{OH})_{4}$, contains approximately $40 \% \mathrm{MgO}$ and are classified as lizardite, chrysotile, and antigorite according to their crystalline structures (Lacinska et al., 2016; Fedoročková et al., 2012). Some mineral beneficiation plant tailings contain high amount of these minerals. Serpentines can be evaluated in $\mathrm{CO}_{2}$ capture and storage application (Wilson et al., 2006, 2009) or in the production of pure magnesium $(\mathrm{Mg})$ metal, $\mathrm{Mg}$ compounds and amorphous silicate $\left(\mathrm{SiO}_{2}\right) \mathrm{Mg}$ in serpentine structure can be easily taken into solution by acid leaching and then can be precipitated as various $\mathrm{Mg}$ compounds. $\mathrm{Mg}$ is an important metal due to some of its characteristic features and used as alloy formation, medicinal products, sulfur removal in iron and steel production, fertilizers, refractory materials, synthesis of Grignard reagent, and fireproof (Raza et al., 2014). The leaching process of the serpentine also leaves amorphous silicate $\left(\mathrm{SiO}_{2}\right)$ as solid residue. Amorphous silicate can be used as a filler and additive in the production of some materials (plastics, rubbers, catalyst carriers, chemical sensors, adhesives, paper, paints, coatings, sealants, and insulating materials) and to improve the mechanical properties of some materials, such as film nanocomposites, and silicon carbide (Bałdyga et al., 2012; Kulikovsky et al., 2008; Wang et al., 1997).

Citation Info: Çiftçi, H., Arslan, B., Bilen, A., Arsoy, Z., Ersoy, B. 2021. Optimization of leaching conditions for extraction of magnesium from a chromite beneficiation plant tailing predominantly containing lizardite. Bulletin of the Mineral Research and Exploration 164, 251-259.

https://doi.org/10.19111/bulletinofmre.827630

*Corresponding author: Hakan ÇİFTÇİ, hakanciftci86@gmail.com 
Serpentines are also the most appealing minerals for the application of carbon dioxide $\left(\mathrm{CO}_{2}\right)$ capture and storage with mineralization (CCSM) which is promising technique that sequences $\mathrm{CO}_{2}$ flue gas into stable magnesium carbonates (Daval et al., 2013; Sanna et al., 2013). CCSM application can be implemented in two ways. The first way involves the direct reaction of mineral and $\mathrm{CO}_{2}$ gas at a given temperature and pressure. In the second method, firstly, the metal is leached from the mineral generally via acids and then reacted with $\mathrm{CO}_{2}$. In both methods, maximum efficiency depends on the structure of the mineral, parameters used in leaching and carbonation (temperature, solid ratio, particle size, chemical concentration, and pressure) (Bobicki et al., 2012; Nduagu et al., 2012; Sanna et al., 2012). CCSM can be seen as an advantageous method due to the easy production of raw material ( $\mathrm{Mg}$ or $\mathrm{Ca}$ rich minerals) and the fact that the raw material has sufficient reserves.

There are many studies on $\mathrm{Mg}$ extraction from serpentine or other $\mathrm{Mg}$ rich minerals by acid leaching (Arce et al., 2017; Lacinska et al., 2016; Liu et al., 2010). According to the literature review, there was no study on investigating $\mathrm{Mg}$ extraction from chromite beneficiation plant tailings, however. This study focused on the optimization of leaching conditions to get maximum $\mathrm{Mg}$ extraction yield from a chromite beneficiation plant tailing predominantly containing lizardite for potential using for CCSM and in producing $\mathrm{Mg}$ compounds. Hydrochloric acid $(\mathrm{HCl})$ and sulphuric acid $\left(\mathrm{H}_{2} \mathrm{SO}_{4}\right)$ were used separately as two different acids. The effects of leaching temperature, solid ratio, acid concentration, and leaching time on the extraction yield of $\mathrm{Mg}$ were investigated separately and optimum leaching conditions were determined. Kinetic studies were also performed to explain leaching mechanism.

\section{Materials and Methods}

\subsection{Materials}

Starting sample (chromite beneficiation plant tailing) was collected from stockpile of chromite beneficiation plant of CVK/Ogelman Mining Co. located in Harmanc1k-Bursa/Turkey. In order to be homogeneous, the sample was collected from several different points by drilling technique. No pretreatment, such as crushing, grinding, or sieving, was carried out before the studies on the collected sample. Hydrochloric acid ( $\mathrm{HCl}, 35-37 \%)$ and sulphuric acid $\left(\mathrm{H}_{2} \mathrm{SO}_{4}, 95-97 \%\right)$ were purchased from Merck, Germany.

\subsection{Characterization Techniques}

Shimadzu XRD-6000 instrument with $\mathrm{Cu}-\mathrm{K} \alpha$ radiation $(\lambda: 1.54184 \AA)$ at $40 \mathrm{kV}$ was used to determine the mineralogical composition of the starting sample and leaching residue. The samples were first dried at $100^{\circ} \mathrm{C}$ for $24 \mathrm{~h}$, ground using a laboratory scaled ring mill, and then scanned with XRD. Morphology of the samples before and after the leaching was investigated using LEO $1430 \mathrm{VP}$ scanning electron microscope (SEM). The chemical compositions of the samples were determined using a Rigaku ZSX Primus II XRF spectrometer (calibrated every 6 months) after the samples dried at $100^{\circ} \mathrm{C}$ for $24 \mathrm{~h}$ and ground using a laboratory scaled ring mill. Particle size distributions were determined by wet sieving using a series of retsch sieves $(150-1,000 \mu \mathrm{m})$.

\subsection{Leaching Experiments}

Leaching experiments were performed using a laboratory scaled three necked glass reactor immersed in a thermo-controlled water bath (Figure 1). Mixing was performed using a mechanic mixer and a condenser was used to avoid loss of acid at high temperatures.

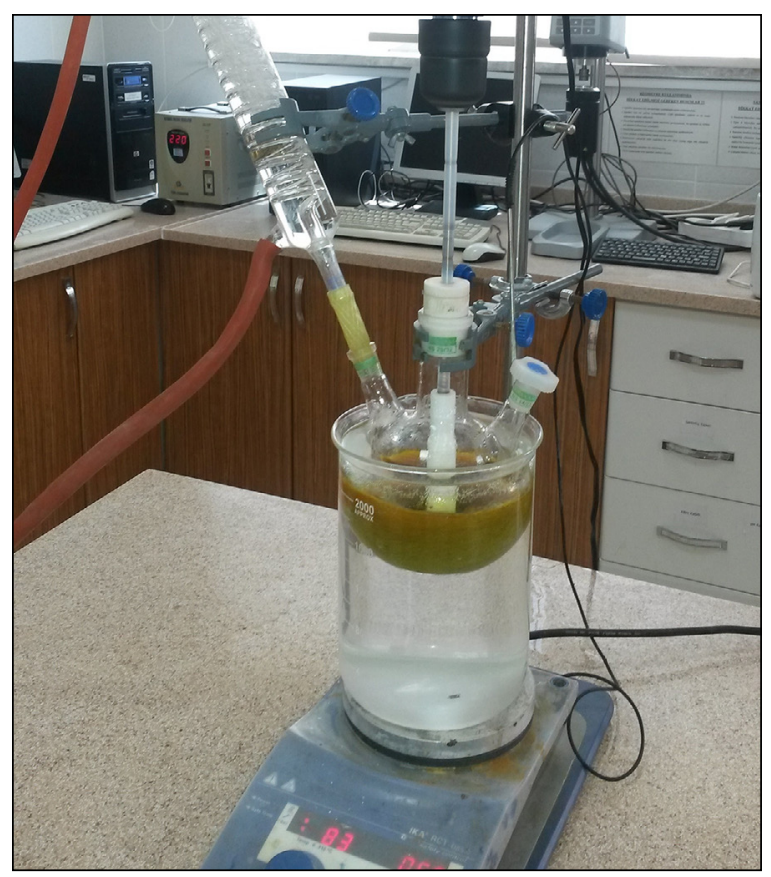

Figure 1- Glass reactor used in the leaching experiments. 
The investigated leaching parameters and their used value ranges are given in the table 1 .

Table 1- Investigated leaching parameters.

\begin{tabular}{|c|c|c|c|}
\hline $\begin{array}{c}\text { Acid concentration } \\
(\mathrm{M})\end{array}$ & $\begin{array}{c}\text { Leaching time } \\
(\mathrm{min})\end{array}$ & $\begin{array}{c}\text { Solid ratio } \\
(\%)\end{array}$ & Temp. $\left({ }^{\circ} \mathrm{C}\right)$ \\
\hline 2 & 30 & 10 & 25 \\
\hline 4 & 60 & 20 & 45 \\
\hline 6 & 90 & 30 & 65 \\
\hline & 120 & 40 & 85 \\
\hline & 150 & & \\
\hline
\end{tabular}

The leaching experiments were performed using both diluted $\mathrm{HCl}$ and $\mathrm{H}_{2} \mathrm{SO}_{4}$ acids separately and started with the investigating the effect of acid concentration. After the acid concentration was optimized, the effects of the leaching time, solid ratio, and temperature were investigated and optimum values were determined. In a typical run, the starting sample (lizardite) was dried at $100^{\circ} \mathrm{C}$ for $24 \mathrm{~h}$ to remove physically adsorbed water first. A certain amount of dried material and $200 \mathrm{~mL}$ of diluted acid $\left(\mathrm{HCl}\right.$ or $\left.\mathrm{H}_{2} \mathrm{SO}_{4}\right)$ were then put in glass reactor. The temperature was then increased to a certain degree and stirring was mechanically started at $800 \mathrm{rpm}$. At the end of the certain leaching time the stirring was stopped and solid/liquid separation was performed via vacuum filtration. Leaching residue was then washed with distilled water, dried at $100^{\circ} \mathrm{C}$ for $24 \mathrm{~h}$, ground using ring mill, and then analyzed by XRF instrument to determine chemical composition. $\mathrm{Mg}$ extraction yield was determined according to XRF analysis data using equation 1 .

Yield, $\%=\frac{(F * f-R * r)}{F * f} * 100$

Where, $F$ is the amount of fed (starting) material (g), $f$ is the $\mathrm{Mg}$ content of fed (starting) material (wt.\%), $R$ is the amount of solid leaching residue $(\mathrm{g})$, and $\mathrm{r}$ is the $\mathrm{Mg}$ content of solid leaching residue (wt.\%).

\section{Results and Discussion}

\subsection{Characterization of the Starting Sample}

Chemical composition of the starting sample according to particle size distribution (Table 2) was obtained from XRF analysis. The data showed that the sample contain high percentage of $\mathrm{SiO}_{2}$ and $\mathrm{MgO}$ ( $>74 \mathrm{wt} . \%$, in total) indicating the presence of serpentine minerals. The sample contains also small amount of iron oxides about $7.1 \mathrm{wt} . \%$. It was also concluded that the $\mathrm{Mg}, \mathrm{Si}$, and $\mathrm{Fe}$ contents showed homogeneous distribution according to particle size distribution (Table 2). This showed that a prebeneficiation according to particle size is not necessary and the leaching experiments should be applied to the entire sample.

XRD pattern of the starting sample (Figure 2) revealed that the sample were constituted by predominantly serpentine mineral of lizardite-1T $\left[\mathrm{Mg}_{3} \mathrm{Si}_{2} \mathrm{O}_{5}(\mathrm{OH})_{4}\right]$ with small amounts of iron silicon $\left(\mathrm{FeSi}_{2}\right)$ and brucite $\left[\mathrm{Mg}(\mathrm{OH})_{2}\right]$.

Particle size distributions (Figure 3 ) revealed that the particles of the starting sample were distributed homogeneously between $100-1,000 \mu \mathrm{m}$ scales. $d_{10}$, $\mathrm{d}_{50}$, and $\mathrm{d}_{90}$ values which can be determined from the curve show cumulative amounts (10-50-90\%) of particles that are smaller than a certain particle size in the sample. For example, $d_{90}$ of the sample means that $90 \%$ of the sample consists of particles with a particle size less than $790 \mu \mathrm{m}$ according to figure 3 .

\subsection{Leaching Experiments}

Serpentine is a 1:1 hydrous magnesium iron phyllosilicate mineral consisting of tetrahedral silicate $\left(\mathrm{SiO}_{2}\right)$ and octahedral brucite $\left(\mathrm{MgOH}_{2}\right)$ layers (Park and Fan, 2004). Leaching of serpentine minerals results in dissolution of the brucite layers

Table 2- Chemical composition of the starting sample according to particle size distribution.

\begin{tabular}{|l|c|c|c|c|c|c|c|c|}
\hline \multirow{2}{*}{ Component } & \multicolumn{9}{|c|}{ Content (wt.\%) } \\
\cline { 2 - 11 } & $\begin{array}{c}\text { Starting } \\
\text { sample }\end{array}$ & $\begin{array}{c}-1,000+850 \\
\mu \mathrm{m}\end{array}$ & $\begin{array}{c}-850+600 \\
\mu \mathrm{m}\end{array}$ & $\begin{array}{c}-600+500 \\
\mu \mathrm{m}\end{array}$ & $\begin{array}{c}-500+425 \\
\mu \mathrm{m}\end{array}$ & $\begin{array}{c}-425+300 \\
\mu \mathrm{m}\end{array}$ & $\begin{array}{c}-300+212 \\
\mu \mathrm{m}\end{array}$ & $\begin{array}{c}-212 \\
\mu \mathrm{m}\end{array}$ \\
\hline $\mathrm{MgO}$ & 39.30 & 39.27 & 39.17 & 39.30 & 39.55 & 39.67 & 39.64 & 39.38 \\
\hline $\mathrm{SiO}_{2}$ & 35.23 & 35.31 & 35.02 & 35.29 & 35.52 & 35.57 & 35.76 & 34.86 \\
\hline $\mathrm{Fe}_{2} \mathrm{O}_{3}$ & 7.08 & 7.08 & 7.00 & 7.01 & 7.01 & 6.81 & 6.78 & 7.02 \\
\hline $\mathrm{LOI}$ & 14.94 & 14.86 & 15.12 & 14.73 & 14.63 & 14.88 & 15.16 & 14.34 \\
\hline
\end{tabular}

LOI: loss of ignition. 


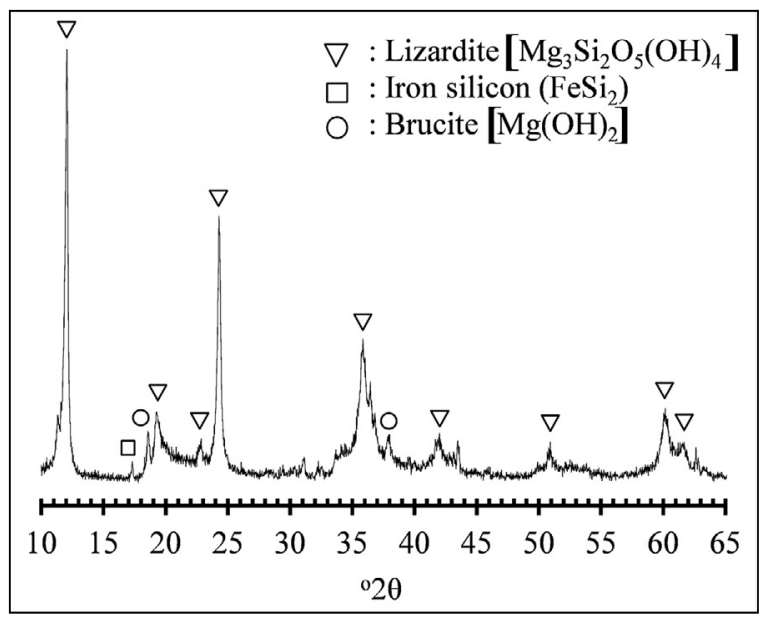

Figure 2- XRD pattern of the starting sample used in the experiments.

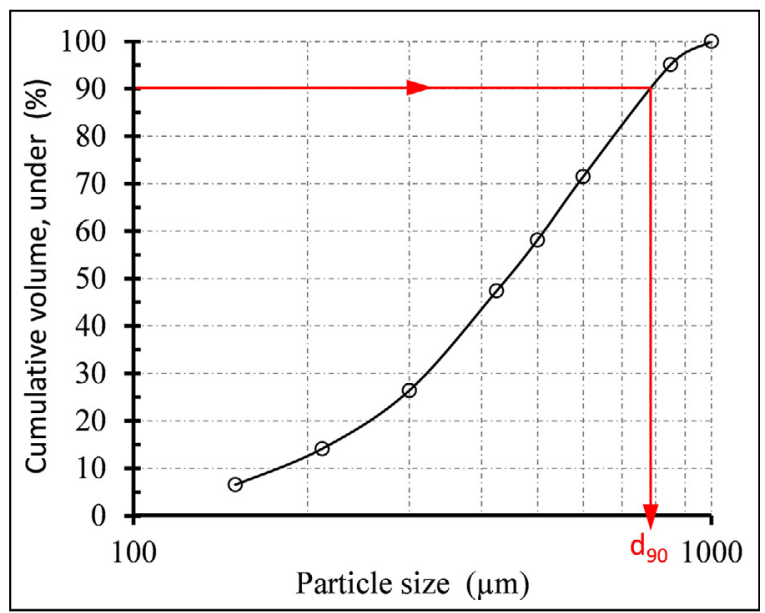

Figure 3- Cumulative particle size distribution of the starting sample.

and remaining amorphous silicate layers (Yoo et al., 2009). It is expected that brucite dissolution rate increases with the increasing of temperature, acid concentration, and time but decreases with increasing of solid ratio. Serpentine dissolution reaction in $\mathrm{HCl}$ and $\mathrm{H}_{2} \mathrm{SO}_{4}$ acids can be explained according to given equation 2 .

$$
\mathrm{Mg}_{3} \mathrm{Si}_{2} \mathrm{O}_{5}(\mathrm{OH})_{4}+6 \mathrm{H}^{+} \rightarrow 3 \mathrm{Mg}^{2+}+2 \mathrm{SiO}_{2}+5 \mathrm{H}_{2} \mathrm{O}
$$

While the effect of acid concentration experiments were performed (Figure 4a), leaching time, solid ratio, and leaching temperature were kept constant as $120 \mathrm{~min}, 20 \mathrm{wt} . \%$, and $85^{\circ} \mathrm{C}$, respectively. Figure 4a revealed that acid concentration had critical effect on the $\mathrm{Mg}$ dissolution rate. Increasing of acid concentration from $2 \mathrm{M}$ to $4 \mathrm{M}$ resulted in increase of
$\mathrm{Mg}$ extraction yields from $\sim 41 \%$ to $~ 75 \%$ and from $75 \%$ to $97 \%$ for $\mathrm{HCl}$ and $\mathrm{H}_{2} \mathrm{SO}_{4}$ acids, respectively. $\mathrm{Mg}$ extraction yield in $\mathrm{H}_{2} \mathrm{SO}_{4}$ acid was higher than $\mathrm{HCl}$ acid at the same concentrations up to $4 \mathrm{M}$ because $\mathrm{H}_{2} \mathrm{SO}_{4}$ contains twice as much $\mathrm{H}^{+}$ion. The dissolution of $\mathrm{Mg}$ in $\mathrm{H}_{2} \mathrm{SO}_{4}$ acid stabilized at $4 \mathrm{M}$, while it increased up to $6 \mathrm{M}$ in $\mathrm{HCl}$ acid concentration. As a result, it was determined that the presence of $4 \mathrm{M} \mathrm{H}_{2} \mathrm{SO}_{4}$ or $6 \mathrm{M} \mathrm{HCl}$ acid in the dissolution media with other parameters kept constant was found to be sufficient to dissolve of the $\geq 98 \mathrm{wt} . \% \mathrm{Mg}$ from lizardite mineral.

Acid concentration, solid ratio, and leaching temperature were kept constant as $4 \mathrm{M} \mathrm{H}_{2} \mathrm{SO}_{4}, 6 \mathrm{M}$ $\mathrm{HCl}, 20 \mathrm{wt} . \%$, and $85^{\circ} \mathrm{C}$, respectively, while the effect of leaching time experiments were performed. By increasing the leaching time up to $60 \mathrm{~min}$, it was found that the dissolution of $\mathrm{Mg}$ increased rapidly, but then the dissolution rate slowed down slightly in the on going periods and stabilized at $120^{\text {th }} \mathrm{min}$ (Figure $4 \mathrm{~b}$ ). Slow progress after fast dissolution in the early stages of leaching was also reported by other studies (Lacinska et al., 2016; Yoo et al., 2009). Rapid dissolution rate in the first $60 \mathrm{~min}$ can be explained by the quick starting of the reaction by easy and quick encounter of hydronium $\left(\mathrm{H}_{3} \mathrm{O}^{+}\right)$ions with free $\mathrm{MgOH}_{2}$ surfaces exposed by size reduction. After the rapid dissolution of free $\mathrm{MgOH}_{2}$ surfaces, $\mathrm{H}_{3} \mathrm{O}^{+}$ions advance the dissolution process more slowly by capillary diffusion between the layers. Optimum leaching time was determined as $120 \mathrm{~min}$ to obtain maximum $\mathrm{Mg}$ extraction ( $98 \mathrm{wt} . \%)$ at given parameters.

Figure $4 \mathrm{c}$ shows the effect of the solid ratio on the $\mathrm{Mg}$ extraction yield. The experiments were performed under changing solid ratios while acid concentration, leaching time, and leaching temperature were kept constant as $4 \mathrm{M} \mathrm{H}_{2} \mathrm{SO}_{4}, 6 \mathrm{M} \mathrm{HCl}, 120 \mathrm{~min}$, and $85^{\circ} \mathrm{C}$, respectively. It was clear from the chart that $20 \mathrm{wt} . \%$ was the optimum solid ratio for the experiments. Increasing solid ratio to $30 \mathrm{wt} . \%$ and $40 \mathrm{wt} . \%$ was resulted in a high drop in $\mathrm{Mg}$ dissolution. When the solid ratio was kept at $10 \mathrm{wt} . \%$ and $20 \mathrm{wt} . \%$, the dissolution yield was almost the same.

The effect of leaching temperature on the extraction yield of $\mathrm{Mg}$ from lizardite was investigated while acid concentration, leaching time, and solid ratio were kept constant as $4 \mathrm{M} \mathrm{H}_{2} \mathrm{SO}_{4}, 6 \mathrm{M} \mathrm{HCl}, 120 \mathrm{~min}$, and 20wt.\%, respectively. Figure $4 \mathrm{~d}$ revealed that temperature has a significant effect on the dissolution of $\mathrm{Mg}$ and increase 

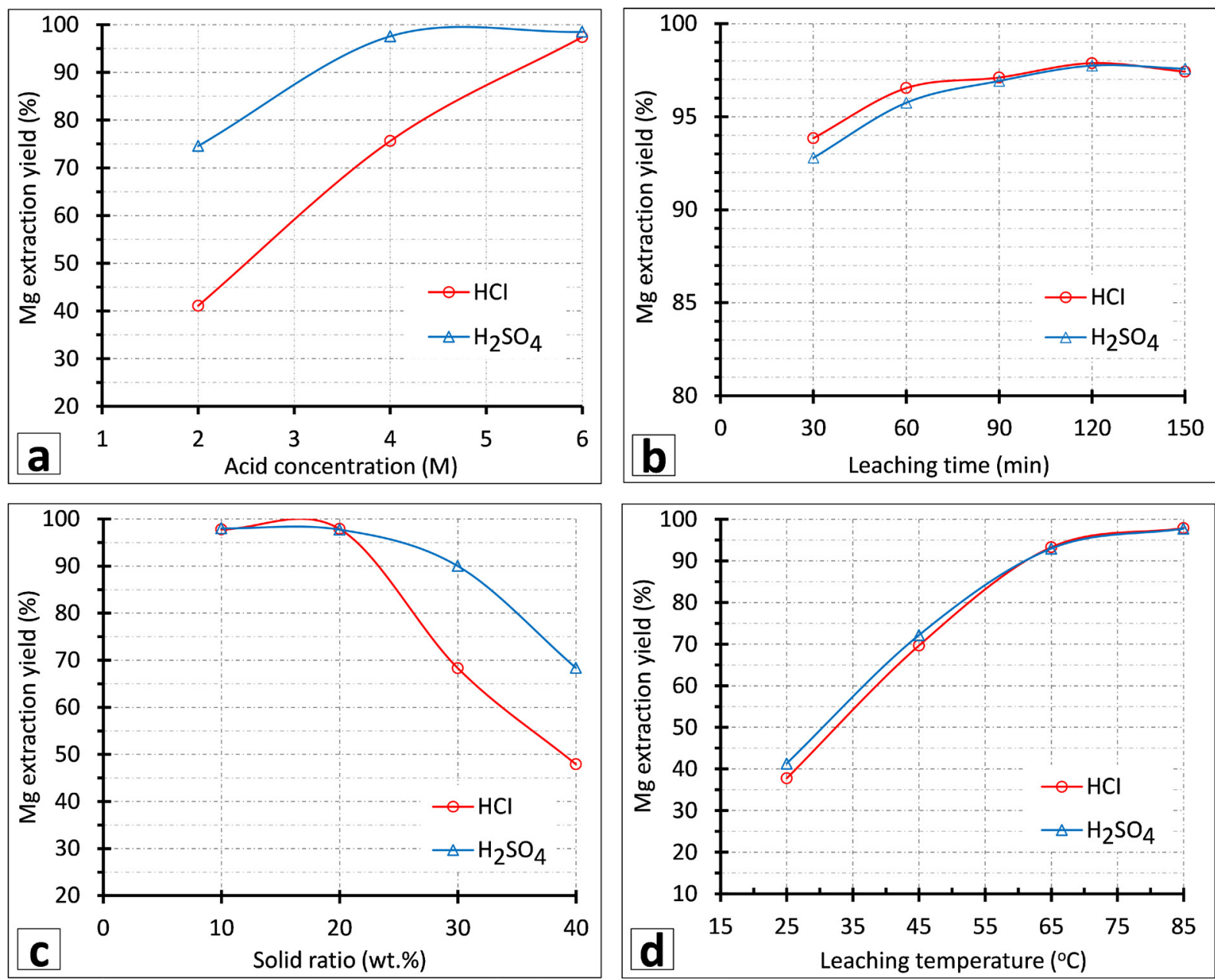

Figure 4- Mg extraction yields versus (a) acid concentration, (b) leaching time, (c) solid ratio, (d) leaching temperature.

in temperature resulted in increasing of dissolution rate highly which similar results were also reported in other studies (Sanna et al., 2013; Yoo et al., 2009; Teir et al., 2007). Increasing of the temperature from $25^{\circ} \mathrm{C}$ to $65^{\circ} \mathrm{C}$ caused a linear increase in $\mathrm{Mg}$ dissolution from $\sim 40 \%$ to $\sim 92 \%$. This result can be related to the increased reactivity of the acids on the $\mathrm{MgOH}_{2}$ layers with increasing temperature. The dissolution rate according to temperature was the same for both $\mathrm{HCl}$ and $\mathrm{H}_{2} \mathrm{SO}_{4}$ acids. Optimum leaching temperature was determined to be $85^{\circ} \mathrm{C}$ to obtain a $\mathrm{Mg}$ extraction yield of about $98 \mathrm{wt} . \%$.

As a result, optimum leaching conditions such as temperature, acid concentration, solid ratio, and leaching time were determined to be $85^{\circ} \mathrm{C}, 20 \mathrm{wt} . \%$, $6 \mathrm{M} \mathrm{HCl}-4 \mathrm{M} \mathrm{H}_{2} \mathrm{SO}_{4}$, and $120 \mathrm{~min}$, respectively.In leaching experiments carried out under optimum conditions, $50 \mathrm{~g}$ of starting material was used and as a result, $21.3 \mathrm{~g}$ of solid leach residue was obtained.
Accordingly, it was found that $28.7 \mathrm{~g}$ of solid was completely dissolved.

\subsection{Characterization of Starting Sample and Leaching Residue}

SEM micrographs (Figure 5a,b) and optic microscope photographs (Figure 5c) revealed that the starting sample generally consisted of light and dark green colored particles with rough surfaces, and have leaf-layer morphology with its angular edges. Figure $5 \mathrm{~d}$,e showed that leaching of the lizardite mineral left particles with porous morphology as a result of dissolution of $\mathrm{MgOH}_{2}$ layers. Additionally, it was also found that the leaching residue particles were predominantly white colored and remained in large sizes (Figure 5f). Dissolution reaction did not affect the original particle size greatly but the residue particles were found to be much softer when tested with hand. This can be explained by the collapsing of 

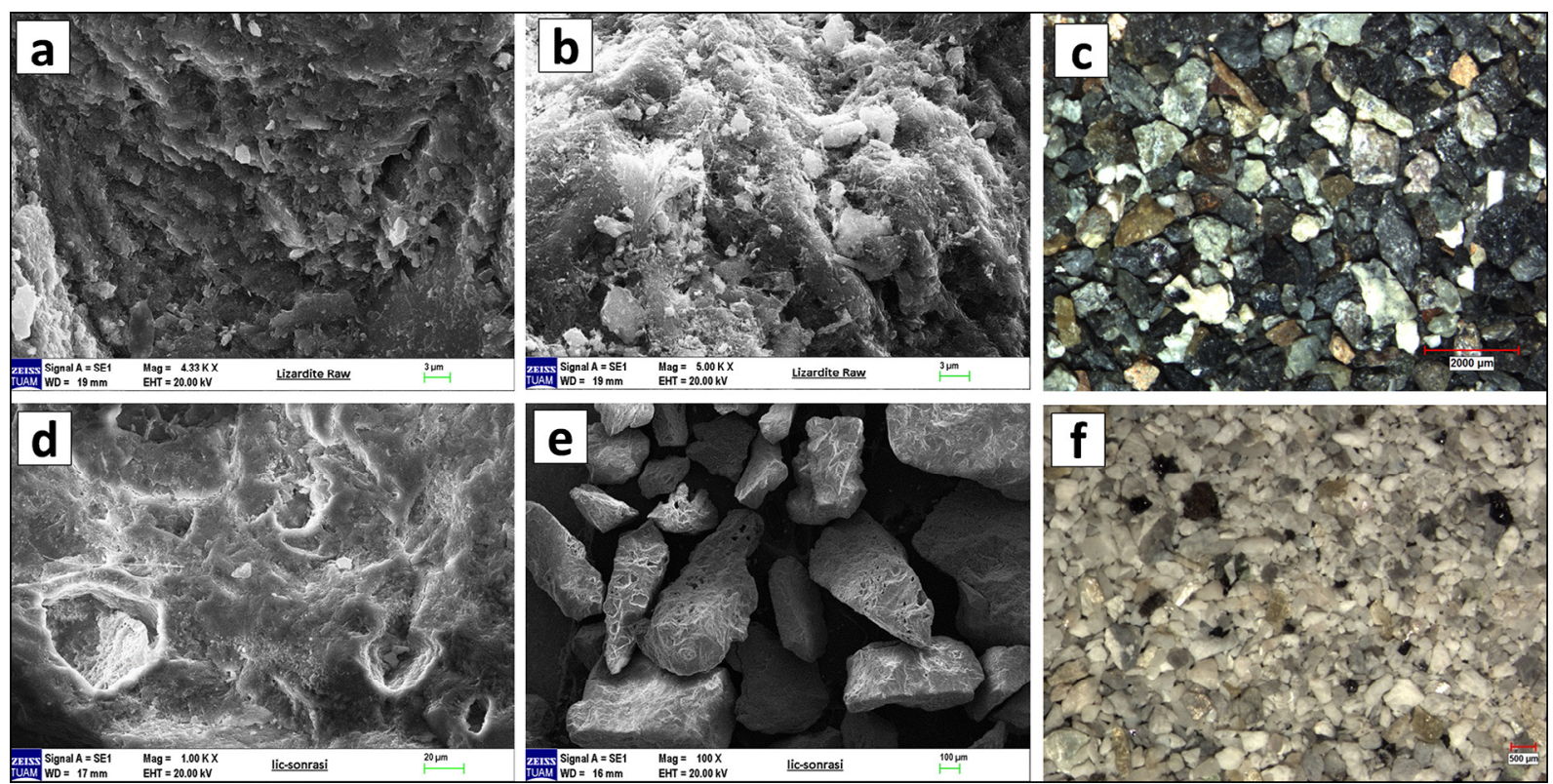

Figure 5- SEM and optic microscope photographs of the starting sample (a,b,c): before leaching, $(\mathrm{d}, \mathrm{e}, \mathrm{f})$ : after leaching.

thin silicate layers under minor pressure as a result of the dissolution of the $\mathrm{MgOH}_{2}$ layer in between.

The lizardite peaks based on the XRD pattern of the starting material in figure 2 were disappeared in the XRD pattern of the leaching residue material (Figure 6) as a result of complete disruption of the crystalline structure. Similar results were obtained by other studies (Arce et al., 2017; Sanna et al., 2013). Arce et al. 2017, investigated the acid leaching of the waste of asbestos fiber (sterile) production which contain serpentine minerals and as a result, the XRD patterns of leaching residue did not show the diffraction lines of brucite and clinochrysotile. Sanna et al., (2013), investigated

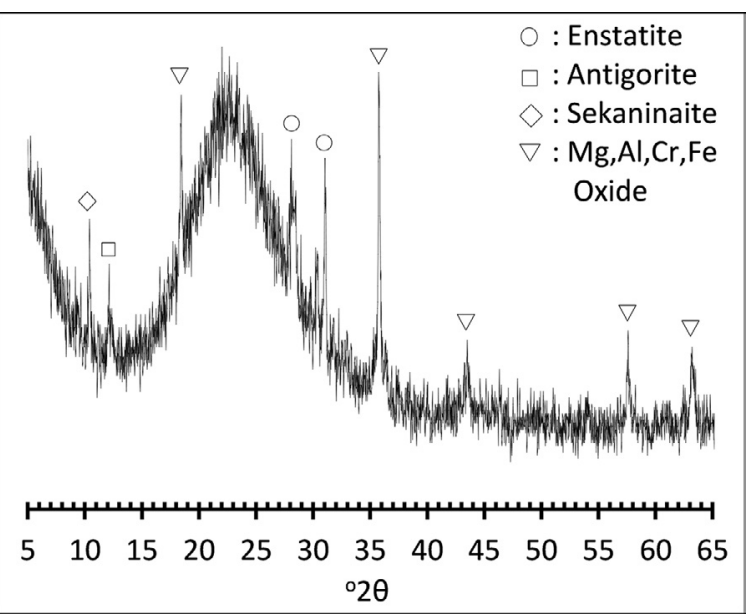

Figure 6- XRD pattern of the leaching residue. leaching conditions of serpentine using ammonium hydroxide solvent and as a result, the amorphous material was obtained at $140^{\circ} \mathrm{C}$. XRD pattern of the leaching residue at optimum parameters (Figure 6) revealed that the residue was predominantly consist of amorphous silicate and small amounts of enstatite $\left(\mathrm{MgSiO}_{3}\right)$, antigorite $\left[\mathrm{Mg}_{3}\left(\mathrm{Si}_{2} \mathrm{O}_{5}\right)(\mathrm{OH})_{4}\right]$, sekaninaite $\left[\left(\mathrm{Fe}^{2+}, \mathrm{Mg}\right)_{2} \mathrm{Al}_{4} \mathrm{Si}_{5} \mathrm{O}_{18}\right]$, and $\mathrm{Mg}, \mathrm{Al}, \mathrm{Cr}, \mathrm{Fe}$ oxide. Broad peak centered at ${ }^{\circ} 2 \theta: 22,5$ represents high amounts of amorphous silicate (Fedoročková et al., 2016; Wang et al., 2006).

\subsection{Leaching Kinetics and Mechanism}

Leaching mechanism of $\mathrm{Mg}$ from lizardite was interpreted according to leaching experiments data and textural properties of lizardite. The textural structure of lizardite mineral (Figure 7d, Mevel, 2003) shows a layered 1:1 (tetrahedral Si layer : octahedral $\mathrm{Mg}$ layer) crystal structure. Leaching mechanism is defined by equation 3 if the reaction is chemically controlled and equation 4 if it is diffusion controlled. It is expected that the curve of the left side of that equation, which is the mechanism that determines the reaction rate, is very close to the linear, and the slope of the drawn curve is equal to the apparent rate constant (Levenspiel, 1972).

$1-(1-X)^{1 / 3}=k . t$ 

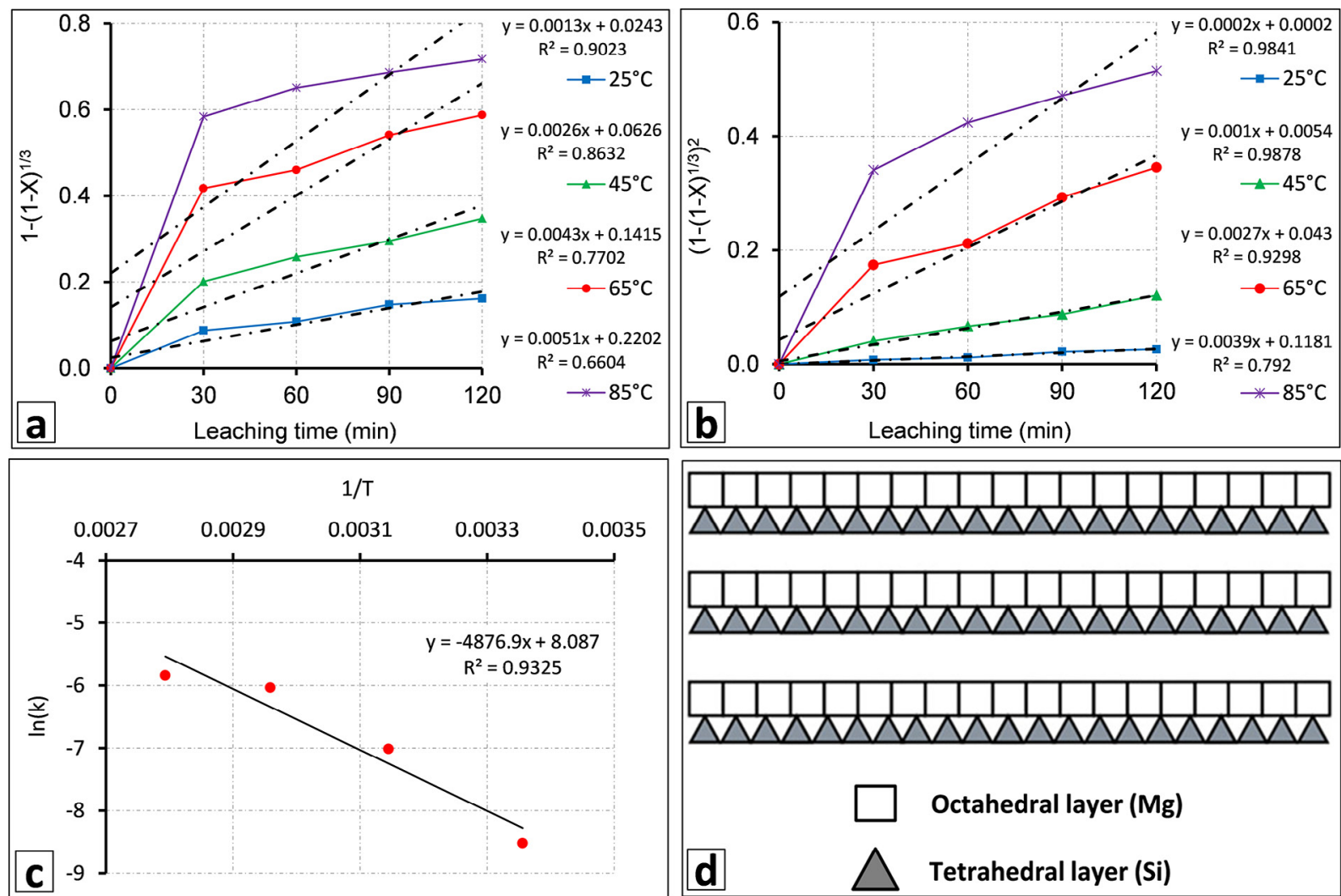

Figure 7- (a,b) Plot of the Mg dissolution results according to equation 3 and equation 4, respectively, (c)lnk- 1/T diagram, (d) chrystal structure of the lizardite.

$\left(1-(1-X)^{1 / 3}\right)^{2}=k \cdot t$

Here, X: fraction of $\mathrm{Mg}$ dissolved (yield/100), k: apparent rate constant $\left(\mathrm{min}^{-1}\right)$, and $\mathrm{t}$ : reaction time (min).

The curves given in figure $7 \mathrm{a}$ and $7 \mathrm{~b}$ were created by using the data obtained from the experiments of dissolution of $\mathrm{Mg}$ in $\mathrm{H}_{2} \mathrm{SO}_{4}$ acid in equations 3 and 4 , respectively. When the curves are examined, the value of $\mathrm{r}^{2}$, which is the correlation coefficient, gave a closer result to 1 in the curves drawn if it was diffusion controlled (Figure 7b) for four temperature values. According to the data obtained, it can be said that the reaction is diffusion controlled. $\mathrm{Mg}$ extraction of lizardite starts with fast dissolution of free octahedral brucite $\left(\mathrm{MgOH}_{2}\right)$ surfaces exposed after crushing and grinding. Initial stage of dissolution cause to formation of pores on the surface and then continues with capillaries formation between the tetrahedral silicate layers. After that $\mathrm{H}_{3} \mathrm{O}^{+}$ions advance the dissolution process more slowly by capillary diffusion. Obtained results are in good agreement with Luce et al. (1972), who reported that the diffusion of ions in the mineral lattice itself or through a product layer is the speed control mechanism for the dissolution of magnesium silicates. Apostolidis and Distin (1978) have also reported same reasons for slowing dissolution of $\mathrm{Mg}$ from serpentine.

Rozalen and Huertas (2013) investigated the dissolution of chrysotile and reported that the dissolution is largely non-stoichiometric and the $\mathrm{Mg}$ layer dissolves ten times faster than silica. This can be attributed to the incongruent leaching process. Incongruent leaching may be a result of the precipitation of dissolved $\mathrm{Si}$ to the surface of the particles (Teir et al., 2007). The formation of a silicarich layer can prevent the continuous leakage of $\mathrm{Mg}$ through the capillaries, which explains why the dissolution rate slows over time (Wang and MarotoValer, 2011). Dissolution rate of $\mathrm{Mg}$ from lizardite was also controlled by diffusion of $\mathrm{Mg}^{2+}, \mathrm{H}_{3} \mathrm{O}^{+}$, and $\mathrm{SO}_{4}^{-2}$ ions throughout the formed capillaries. According to these results, it can be said that the leaching process 
of serpentine minerals is completed by dissolution of almost all of the octahedral Mg layers and a very small amount of the tetrahedral Si layers. At the end of the dissolution of the serpentine mineral, amorphous silicate remains as solid state while $\mathrm{Mg}$ is taken into the solution as a cation. Activation energy (EA) was calculated using the Arrhenius equation (Equation 5).

$\mathrm{k}=\mathrm{A} \cdot \exp ^{-\mathrm{E}_{\mathrm{A}} / \mathrm{R} \cdot \mathrm{T}}$

Here, $k$ : apparent rate constant $\left(\mathrm{min}^{-1}\right), A$ : frequency factor, $R$ : gas constant $(\mathrm{R}=8.314 \mathrm{~J} / \mathrm{molK})$ and $T$ :reaction temperature $(\mathrm{K})$.

When logarithm of both sides of equation 5 is taken and frequency factor $\mathrm{A}$ is accepted as 1, equation 6 is obtained.The slope of the curve given in the figure $7 \mathrm{c}$ gives lnk.T $(-4,876.9)$ and activation energy can be calculated when this value is placed in equation 6 .

$\ln \mathrm{k}=\frac{-\mathrm{E}_{\mathrm{A}}}{\mathrm{R} \cdot \mathrm{T}}$

Activation energy of the leaching experiment under optimum conditions was determined to be 40.55 $\mathrm{kJ} / \mathrm{mol}$.

\section{Conclusions}

$\mathrm{XRF}$ and XRD analysis revealed that the chromite plant tailing sample was predominantly consisted of $\mathrm{Mg}$ rich lizardite mineral. $\mathrm{Mg}$ and other elements in the sample were distributed homogenously according to particle size distribution. Dissolution of $\mathrm{Mg}$ from lizardite in $\mathrm{HCl}$ and $\mathrm{H}_{2} \mathrm{SO}_{4}$ acids using a glass reactor was investigated successfully. Optimum leaching conditions such as temperature, acid concentration, solid ratio, and leaching time were determined to be $85^{\circ} \mathrm{C}, 20 \mathrm{wt}$. $\%, 6 \mathrm{M} \mathrm{HCl}-4 \mathrm{M} \mathrm{H}_{2} \mathrm{SO}_{4}$, and $120 \mathrm{~min}$, respectively. Maximum $\mathrm{Mg}$ extraction yield for both two acids was determined to be nearly $98 \mathrm{wt}$. $\%$. The results showed that chromite tailings predominantly containing lizardite can be potentially used for CCSM and in producing Mg compounds. Leaching of lizardite left a solid residue mainly composed of amorphous silicate which can be used in various applications. Kinetic studies revealed that the dissolution of $\mathrm{Mg}$ from lizardite was found to follow Jander equation. Diffusion of $\mathrm{Mg}^{2+}, \mathrm{H}_{3} \mathrm{O}^{+}$, and $\mathrm{SO}_{4}{ }^{2-}$ ions throughout the capillaries formed between tetrahedral silicate layers controlled the reaction speed rate.

\section{References}

Apostolidis, C.I., Distin, P.A. 1978. The kinetics of the sulphuric acid leaching of nickel andmagnesium fromreduction roasted serpentine. Hydrometallurgy 3, 181-96.

Arce, G.L.A.F., Neto, T.G.S., Ávila, I., Luna, C.M.R., Carvalho, J.A. 2017. Leaching optimization of mining wastes with lizardite and brucite contents for use in indirect mineral carbonation through the $\mathrm{pH}$ swing method. Journal of Cleaner Production $141,1324-1336$.

Bałdyga, J., Jasińska, M., Jodko, K., Petelski, P. 2012. Precipitation of amorphous colloidal silica from aqueous solutions-Aggregation problem. Chemical Engineering Science 77, 207-216.

Bobicki, E.R., Liu, Q., Xu, Z., Zeng, H. 2012. Carbon capture and storage using alkaline industrial wastes. Progress in Energy and Combustion Science 38, 302-20.

Daval, D., Hellmann, R., Martinez, I., Gangloff, S., Guyot, F. 2013. Lizardite serpentine dissolution kinetics as a function of $\mathrm{pH}$ and temperature, including effects of elevated $\mathrm{pCO}_{2}$. Chemical Geology 351, 245-256.

Fedoročková, A., Hreus, M., Raschman, P., Sučik, G. 2012. Dissolution of magnesium from calcined serpentinite in hydrochloric acid. Minerals Engineering 32, 1-4.

Fedoročková, A., Raschman, P., Sučik, G., Ivánová D., Kavuličová, J. 2016. Utilization of chrysotiletype tailings for synthesis of high-grade silica by controlled precipitation. Mineral Processing and Extractive Metallurgy Review 37(5), 287-294.

Kulikovsky, V., Vorlíček, V., Boháč, P., Stranyánek, M., Čtvrtlík, R., Kurdyumov, A. 2008. Mechanical properties of amorphous and microcrystalline silicon films.Thin Solid Films 516(16),53685375 .

Lacinska, A. M., Styles, M. T., Bateman, K., Wagner, D., Hall, M.R., Gowing, C., Brown, P. D. 2016. Acid-dissolution of antigorite, chrysotile and lizardite for ex situ carbon capture and storage by mineralization. Chemical Geology 437, 153-159.

Levenspiel, O. 1972. Chemical Reaction Engineering. John Wiley and Sons.2,13-29.

Liu, K., Chen, Q., Hu, H., Yin, Z. 2010. Characterization and leaching behaviour of lizardite in Yuanjiang laterite ore. Applied Clay Science 47, 311-316.

Luce, R.W., Bartlett, R.W., Parks, G.A. 1972. Dissolution kinetics of magnesium silicates. Geochimica et Cosmochimica Acta 36, 35-50. 
Mevel, C. 2003. Serpentinization of abyssal peridotites at mid-ocean ridges. Comptes Rendus Geoscience 335(10-11), 825-852.

Nduagu, E., Björklöf, T., Fagerlund, J., Wärnå, J., Geerlings, H., Zevenhoven, R. 2012. Production of magnesium hydroxide from magnesium silicate for the purpose of $\mathrm{CO}_{2}$ mineralisation - Part 1: Application to Finnish serpentinite. Minerals Engineering 30, 75-86.

Park, A.H.A., Fan, L.S. 2004. $\mathrm{CO}_{2}$ mineral sequestration: physically activated dissolution of serpentine and $\mathrm{pH}$ swing process. Chemical Engineering Science 59(22-23), 5241-5247.

Raza, N., Zafar, Z.I., Najam-ul-Haq, M. 2014.Utilization of formic acid solutions in leaching reaction kinetics of natural magnesite ores. Hydrometallurgy 149 , 183-188.

Rozalen, M., Huertas F. J. 2013. Comparative effect of chrysotile leaching in nitric, sulfuric and oxalic acids at room temperature. Chemical Geology $352,134-142$.

Sanna, A., Dri, M., Hall, M.R., Maroto-Valer, M. 2012. Waste materials for carbon capture and storage by mineralisation (CCSM) - A UK perspective. Applied Energy 99, 545-554.

Sanna, A., Wang, X., Lacinska, A., Styles, M., Paulson, T., Maroto-Valer, M.M. 2013. Enhancing Mg extraction from lizardite-rich serpentine for $\mathrm{CO} 2$ mineral sequestration. Minerals Engineering 49, 135-144.
Teir, S., Revitzer, H., Eloneva, S., Fogelholm, C.J., Zevenhoven, R. 2007. Dissolution of natural serpentinite in mineral and organic acids. International Journal of Mineral Processing 83, 36-46.

Wang, Z., Yang, H., Wang, L., Zhao, M. 1997.Preparation of ultrafine $\mathrm{SiO}_{2}$ with high surface area by the chemical precipitation method. Materials Science and Engineering 48, 211-214.

Wang, L., Lu, A., Wang, C., Zheng, X., Zhao, D., Liu, R. 2006. Nano-fibriform production of silica from natural chrysotile.Journal of Colloid and Interface Science 295, 436-439.

Wang, X., Maroto-Valer, M.M. 2011. Dissolution of serpentine using recyclable ammonium salts for $\mathrm{CO}_{2}$ mineral carbonation. Fuel 90(3), 1229-1237.

Wilson, S.A., Raudsepp, M., Dipple, G.M. 2006. Verifying and quantifying carbon fixation in minerals from serpentine-rich mine tailings using the Rietveld method with X-ray powder diffraction data. American Mineralogist 91, 1331-1341.

Wilson, S.A., Dipple, G.M., Power, I.M., Thom, J.M., Anderson, R.G., Raudsepp, M., Gabites, J.E., Southam, G. 2009. Carbon dioxide fixation within mine wastes of ultramafic-hosted ore deposits: examples from the Clinton Creek and Cassiar Chrysotile, Canada. Economic Geology 104, 95112.

Yoo, K., Kim, B.S., Kim, M.S., Lee, J., Jeong, J. 2009. Dissolution of magnesium from serpentine mineral in sulfuric acid solution. Materials Transactions 50(5), 1225-1230. 
